\title{
Histology, Histochemistry and Ultrastructure of the Cloacal Lymphoid Tissue in White Leghorn Chicken
}

\author{
V. R. Indu ${ }^{\text {1* }}$, K. M. Lucy ${ }^{2}$, N. Ashok ${ }^{2}$ and S. Maya ${ }^{1}$ \\ ${ }^{1}$ Department of Veterinary Anatomy and Histology, College of Veterinary and Animal \\ Sciences, Mannuthy, Thrissur, Kerala-680651, India \\ ${ }^{2}$ Controller of examinations, Kerala Veterinary and Animal Sciences University, Pookode, \\ Wayanad, Kerala-673576, India \\ *Corresponding author
}

Keywords

Cloaca, Lymphoid Tissue, Histology, Histochemistry, Ultrastructure, Chicken

Article Info

Accepted:

07 November 2019

Available Online:

10 December 2019

\section{A B S T R A C T}

Histology, histochemistry and ultrastructure of the lymphoid tissue in cloaca were studied in six White Leghorn chickens of three months of age. The lymphoid patches were distributed along the dorsal wall of the proctodeum of cloaca in all the birds. The tunica mucosa of cloacal lymphoid tissue consisted of a simple tall columnar lining epithelium which was modified into a lymphoepithelium. The scattered and aggregared lymphoid tissue were located in the lamina propria mucosae and submucosa. The goblet cells were lacking in proctodeum. But strong periodic acid Schiff's (PAS) positive reaction was seen in proctodeal glands. The fibroblastic reticulum cell (FRC) in lamina propria, gave a reticular reaction for acid phosphatase. Since the lymphoid tissue was well developed in the cloacal patch further studies are required for identification of sites for local vaccine application for effective mucosal immune response in this species.

\section{Introduction}

In birds, as in mammals, a specialized branch of local immune system called mucosaassociated lymphoid tissue (MALT) protects the mucosal surfaces. Gut-associated lymphoid tissue (GALT) seen in digestive system forms the main component of MALT in birds (Befus et al., 1980). The lymphoid tissue in cloaca is anatomically located along the proctodeum of the cloaca. Therefore, it is continuously exposed to environmental antigens, allergens, infectious agents, chyme and faeces. Recently researches involving 
avian GALT are gaining momentum especially in the development of cloacal vaccines.

\section{Materials and Methods}

For the present study cloaca of six White Leghorn chicken of six to eight weeks of age were collected, cleaned and processed routinely to obtain 5-6 $\mu \mathrm{m}$ thick serial paraffin sections. The sections were stained by Haematoxylin and Eosin (Luna, 1968), Gomori's rapid one step trichrome method for collagen fibres (Luna, 1968), Verhoeff's method for elastic fibres (Singh and Sulochana, 1996), Gordon and Sweet's method for reticular fibres (Bancroft and Gamble, 2003), PAS-Alcian blue method for mucosubstances $\mathrm{pH} 2.5$ (Luna, 1968), Gomori's lead acetate method for acid phosphatase (Bancroft and Gamble, 2003) and Acid alpha naphthyl acetate (ANAE) technique for histological identification of Tlymphocytes (Ranki et al., 1976).

For scanning electron microscopy samples were fixed in 2.5 per cent gluteraldehyde in $0.1 \mathrm{M}$ phosphate buffer (PBS) $(\mathrm{pH}$ 7.2) for 24 $\mathrm{h}$ at $4^{\circ} \mathrm{C}$ and post fixed in two per cent aqueous osmium tetroxide for four hours. Thereafter the samples were processed and scanned under Scanning Electron Microscope (SEM-Model: JEOL-JSM 5600) at required magnifications at Ruska Labs, College of Veterinary Science, Rajendranagar, Hyderabad, Telangana.

\section{Results and Discussion}

The lymphoid tissue in cloaca in White Leghorn chicken were distributed along the dorsal wall of the proctodeum in all the birds studied as reported earlier by Olah et al., (2003). In parallel with the reports of Bacha and Bacha (2000) in chicken, the tunica mucosa of cloacal lymphoid tissue consisted of a simple tall columnar lining epithelium with few goblet cells and heavy lymphoid cell infiltration into the lamina propria mucosae and the tela submucosa of the dorsal wall of the proctodeum. In some places, the epithelium was heavily infiltrated with lymphocytes, macrophages and plasma cells and formed a lymphoepithelium (LE) (Fig. 1). Lymphoid tissues in the lamina propria mucosae and the tela submucosa consisted of scattered and aggregated lymphoid cells as reported by Bacha and Bacha (2000) in chicken. Densely packed large and small lymphocytes with few macrophages, plasma cells and many mitotic figures were recorded. Large numbers of capillaries were seen in the lamina propria and submucosa in all the birds under study. These observations are parallel to the reports of Dolfi et al., (1988) and Budras and Konig (2001) in birds. The presence of high endothelial venules (HEV) within these regions was suggestive of a close immunological association of the cloacal lymphoid tissue with other lymphoid organs (Nagy et al., 2005).

\section{Carbohydrates}

The goblet cells were lacking in proctodeum, in agreement with the results of Oliveira et al., (2004). Strong periodic acid Schiff's (PAS) positive reaction was seen in the proctodeal glands as observed by Joshi and Meshram (2018).

\section{Acid Phosphatase (ACP)}

In lamina propria, the fibroblastic reticulum cell (FRC) gave a reticular reaction however ACP reaction was not seen in the lymphocytes (Fig. 2). According to Heusermann et al., (1982) the FRCs were mesenchymal cells which formed a special arrangement with reticular fibres at distinct circumscriptive areas for placement of lymphocytes and macrophages. 
Fig.1 C. S. of cloacal lymphoid tissue showing lamina propria H\&E x 100

1. Lymphoepithelium

2. Crypts of Liberkuhn

3. Lymphoid tissue

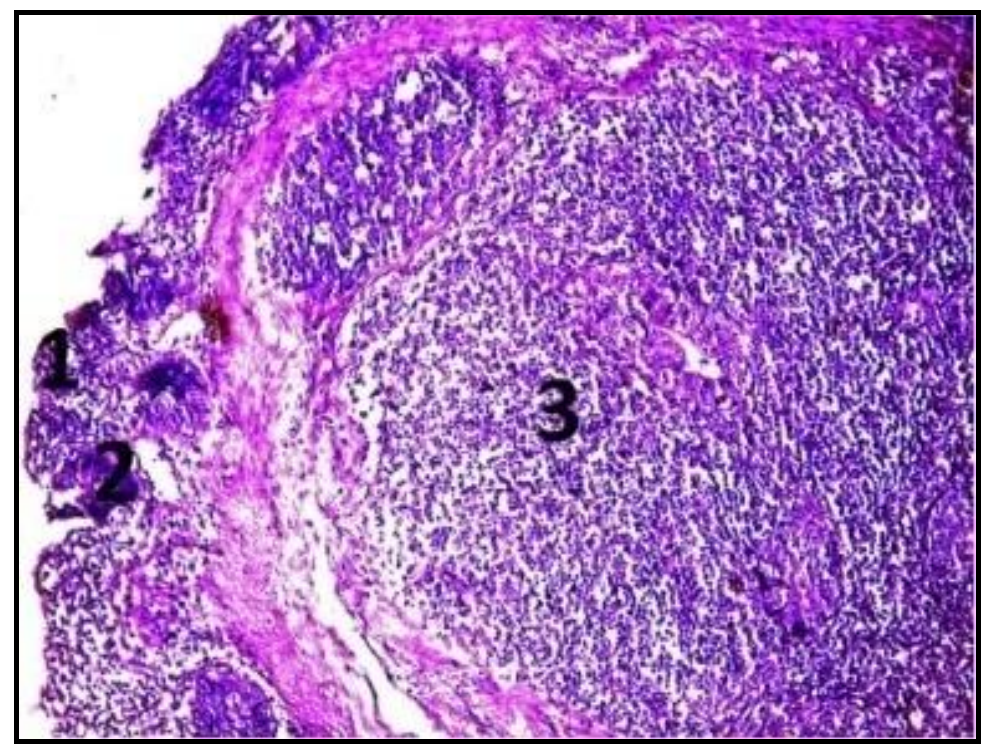

Fig.2 C. S. of cloacal lymphoid tissue showing reticular reaction of acid phosphatase. Azo dye

1. Lymphoepithelium coupling method x 100

2. Lymphoid tissue

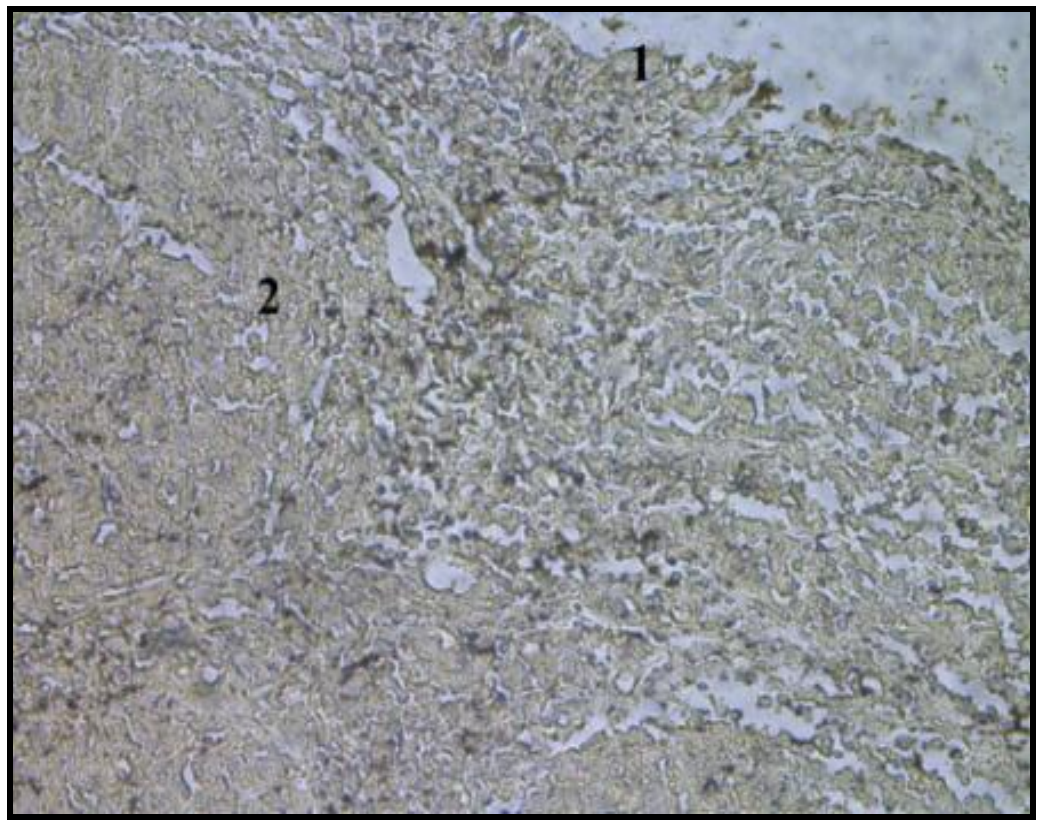


Fig.3 C. S. of cloacal lymphoid tissue showing alpha naphthyl acetate esterase activity

1. ANAE positive T lymphocytes

\section{ANAE x200}

2. Crypts of Liberkuhn

3. Germinal centre

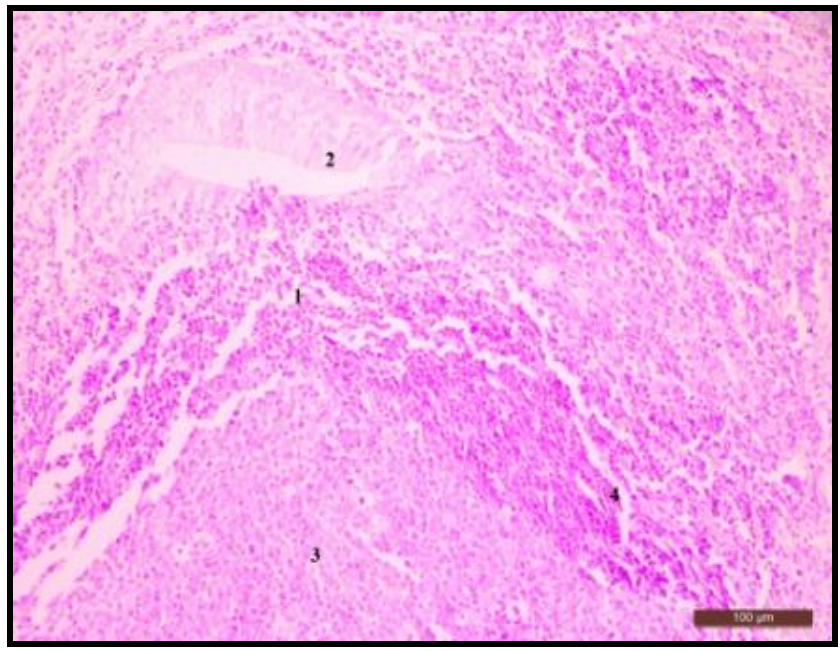

Fig.4 Scanning electron microscopy of cloacal lymphoid tissue showing lamina propria SEMX70

1. Lymphoid tissue

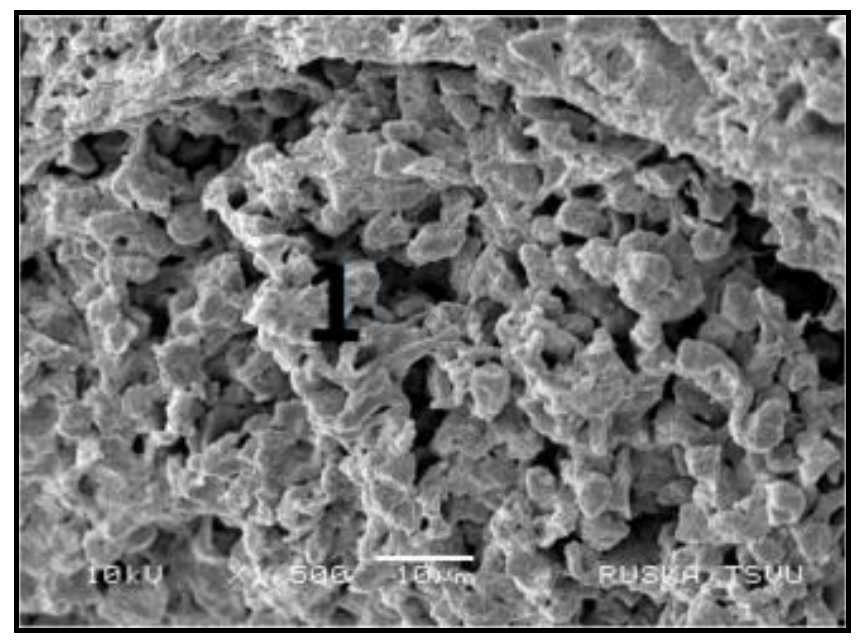

\section{Alpha-Naphthyl Acetate Esterase (ANAE)}

Presence of fine-granular ANAE activity was seen in the cytoplasm of lymphocytes and macrophages in the lamina propria and submucosa (Fig. 3). T cells could be demonstrated by the presence of dot-like
ANAE activity in their cytoplasm, in the Tdependent areas of the tonsil and beneath the crypt epithelium (Crocker et al., 1983).

\section{Scanning Electron Microscopy (SEM)}

In the SEM, surface epithelium of the cloacal lymphoid tissue in chicken consisted of 
columnar cells, few goblet cells and numerous lymphoid cells in between. In cut sections below the surface epithelium, numerous lymphocytes and rounded sac-like follicles with interfollicular area between them were seen (Fig. 4). These observations are in accordance with the reports of Bacha and Bacha (2000) in chicken.

Since the lymphocytes carry out the activities of immune system, it may be interpreted that in chicken the lymphoid tissue in the proctodeum of cloaca might also be important for local immunity as antigens present in the chyme and faeces have easy access to this lymphoid tissue (Dolfi et al., 1988). To develop effective cloacal vaccines, the existence of the cloacal lymphoid tissue has to be taken into account and studied in detail.

\section{References}

Bacha, W.J. and Bacha, L.M. (2000). Color Atlas of Veterinary Histology. $\left(2^{\text {nd }} \mathrm{Ed}\right.$.) London: Lippincott Williams and Wilkins.pp71

Bancroft, J.D. and Gamble, M. (2003). Theory and Practice of Histological Techniques. $\quad\left(5^{\text {th }}\right.$ Ed.). Churchill Livingstone, New York, 796p.

Befus A.,D., Johnston, N., Leslie G.,A. and Bienenstock, J. (1980). Gut-associated lymphoid tissue in the chicken. I. Morphology, ontogeny, and some functional characteristics of Peyer's patches. J Immunol. 125: 2626-32.

Budras, K.D. and Konig, H.E. (2001). Immune system and lymphatische Organe (Organa lymphopoetica). In H.E. Konig and H.G. Liebich (eds.). Anatomie und Propa"deutik des Geflu" gels. Stuttgart: Schattauer, pp. 161 168.

Crocker, J., Jones, E.L. and Curran, R.C. (1983). The form factor of alphanaphthyl acetate esterase positive cells in non-Hodgkin's lymphomas and reactive lymph nodes. J. Clin. Pathol. 36: 303-306.

Dolfi, A., Bianchi, F. and Lupetti, M. (1988). Distribution of B-lymphocytes in the areas of bursal and cloacal lymphoid infiltration. Journal of Anatomy. 160: $201-210$.

Heusermann, U., Schroeder, L., Zurborn, K.H. and Stutte, H.J. (1982). Structure and function of stroma cells in lymphoid tissue. In: Goos, M. and Christophers E. (eds.), Lymphoproliferative Diseases of the Skin. Springer-Verlag, Berlin, pp. 25-33.

Joshi H and Meshram B. 2018. Gross, Histomorphological and Histochemical Studies of the Cloaca in White Leghorn Fowl (Gallus domesticus domesticus). Indian J. Vet. Anat.30(2):134-136

Luna, L.G. (1968). Manual of Histological Staining Methods of the Armed Forces Institute of Pathology. ( $3^{\text {rd }} \mathrm{Ed}$.). Mc Graw-Hill Book Company, New York, $258 \mathrm{p}$.

Nagy, N., Igya'rto’, B., Magyar, A., Gazdag, E., Palya, V. and Olah, I. (2005). Oesophageal tonsil of the chicken. Acta Veterinaria Hungarica. 53: $173-$ 188.

Oliveira, C.A., Silva, R.M., Santos, M.M. and Mahecha, G.A.B. 2004. Location of the ureteral openings in the cloacas of tinamous, some ratite birds, and crocodilians: A primitive character. Journal of Morphology 260: 234- 246.

Olah, I., Nagy, N., Magyar A. and Palya V. (2003). Oesophageal tonsil: A novel gut-associated lymphoid organ. Poult. Sci. 82:767-770

Ranki, A., Totterman, T. A. and Hayry, P. (1976). Identification of resting human $\mathrm{T}$ and $\mathrm{B}$ lymphocytes by acid $\alpha$ naphthyl acetate esterase staining combined with rosette formation with 
Staphylococcus aureus strain Cowan 1. Scand. J. Immunol. 5: 1129-1138.

Singh, U.B. and Sulochana, S. (1996).
Handbook of Histological and Histochemical Techniques. Premier Publishing House, Hyderabad, 111p.

\section{How to cite this article:}

Indu, V. R., K. M. Lucy, N. Ashok and Maya, S. 2019. Histology, Histochemistry and Ultrastructure of the Cloacal Lymphoid Tissue in White Leghorn Chicken. Int.J.Curr.Microbiol.App.Sci. 8(12): 607-612. doi: https://doi.org/10.20546/ijcmas.2019.812.079 